\title{
Persistent detection of dengue virus RNA in vaginal secretion of a woman returning from Sri Lanka to Italy, April 2017
}

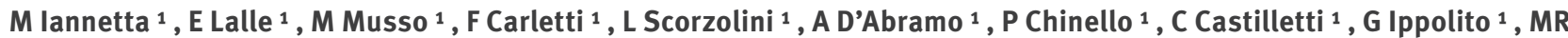 \\ Capobianchi ${ }^{1}$, E Nicastri ${ }^{1}$ \\ 1. National Institute for Infectious Diseases 'Lazzaro Spallanzani', IRCCS, Rome, Italy
}

Correspondence: Marco lannetta (marco.iannetta@inmi.it)

Citation style for this article:

lannetta M, Lalle E, Musso M, Carletti F, Scorzolini L, D’Abramo A, Chinello P, Castilletti C, Ippolito G, Capobianchi MR, Nicastri E. Persistent detection of dengue virus RNA in vaginal secretion of a woman returning from Sri Lanka to Italy, April 2017. Euro Surveill. 2017;22(34):pii=30600. D0I: http://dx.doi.org/10.2807/15607917.ES.2017.22.34.30600

Article submitted on 01 August 2017 / accepted on 23 August 2017 / published on 24 August 2017

We describe the dynamics of dengue virus (DENV) infection in a woman in her mid-30s who developed fever after returning from Sri Lanka to Italy in April 2017. Laboratory testing demonstrated detectable DENV-RNA in plasma, urine, saliva, vaginal secretion. Persistent shedding of DENV-RNA was demonstrated in vaginal secretion, and DENV-RNA was detectable in the pelleted fraction up to 18 days from symptom onset. These findings give new insights into DENV vaginal shedding and vertical transmission.

We present a case of primary dengue fever (DF) in a Caucasian woman returning from Sri Lanka to Italy in April 2017. Dengue virus (DENV) RNA was persistently detected in vaginal secretion up to 18 days from symptom onset (FSO).

\section{Case report}

In April 2017, a Caucasian woman in her mid-30s returning to Italy from a 19-day travel in Sri Lanka, experienced a 3 -day course of fever $\left(>38.5^{\circ} \mathrm{C}\right)$, arthralgia, weakness and headache. On admission at the National Institute for Infectious Diseases Lazzaro Spallanzani in Rome, Italy (day 3 FSO), a commercial dengue rapid test (Dengue DUO, Standard Diagnostics Inc., Kyonggi-do, Korea), detecting specific IgG, IgM and non-structural (NS)-1 protein, revealed NS-1 antigen reactivity only. Routine laboratory tests showed transient leukopenia and thrombocytopenia, with slight increase of liver enzymes and alterations of coagulation parameters (Figure).

On day 4 FSO, DENV-specific IgG and IgM, assessed by indirect immune fluorescence assay (IFA, Arboviral Fever Mosaic-2, IgM and IgG, Euroimmun, Hamburg, Germany), were below the detection threshold (1/20), and real-time PCR for DENV (CDC DENV-1-4 RealTime RT-PCR Assay, Atlanta, United States (US)) was positive in serum (cycle threshold $(\mathrm{Ct}): 22$ ); hence the diagnosis was primary DENV infection. Viral RNA was also detected in urine (Ct: 34.61), saliva (Ct: 33.55 ) and vaginal secretion (Ct: 30.71). The latter was collected by flocked swab and immediately suspended in $2 \mathrm{~mL}$ of vaginal swab transport medium (VSTM) at $4^{\circ} \mathrm{C}$ in a $15-\mathrm{mL}$ sterile tube. Moreover, a pan-flavivirus genus-specific nested RT-PCR targeting the NS-5 gene (modified from [1]) followed by the amplicon sequencing, showed DENV type 2 in all the collected samples (saliva, urine, serum and vaginal swab). The virological investigation for DENV was repeated on longitudinally collected samples (Table).

Rapid test, thin and thick smear and PCR for malaria were all negative; chikungunya and Zika virus serologies were negative as well as specific PCR in serum and urine. Epstein-Barr virus and Cytomegalovirus serology indicated past infections, with negative $\lg M$ for both viruses.

On day 10 FSO, serum, urine, saliva, and vaginal swab were collected, and DENV-RNA was still detectable in all the samples (serum Ct: 32.96; urine Ct: 31.50; saliva Ct: 37.29; VSTM Ct: 35.47). VSTM was centrifuged at $1,500 \mathrm{rpm}$ for 10 minutes to obtain supernatant fractions (SNF) and pelleted fractions (PeF). Total RNA was extracted from SNF and PeF using the COBAS AmpliPrep Total Nucleic Acid Isolation Kit (Roche, Indianapolis, Indiana, US) and Trizol (Life Technologies, Stockholm, Sweden) respectively, according to the manufacturer's instructions. RT-PCR for DENV-RNA resulted positive in SNF and PeF with a Ct of 35.47 and 33.34, respectively.

On day 18 FSO, DENV-RNA was detectable only in urine (Ct: 32.53), while it was undetectable in serum, saliva and VSTM. After separation of VSTM, DENV-RNA was 


\section{FIGURE}

Laboratory tests performed during hospitalisation, case of dengue fever, Italy, April 2017

A

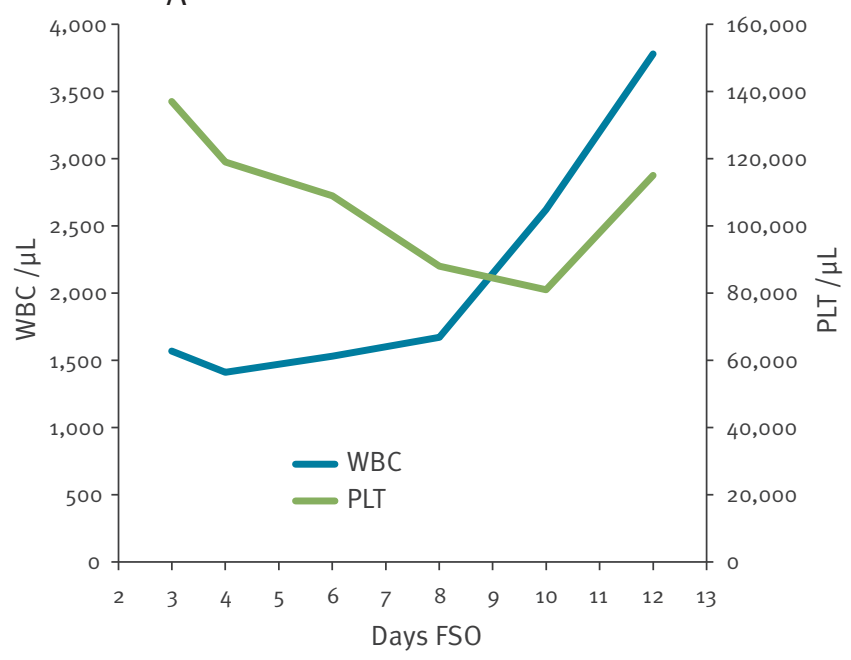

B

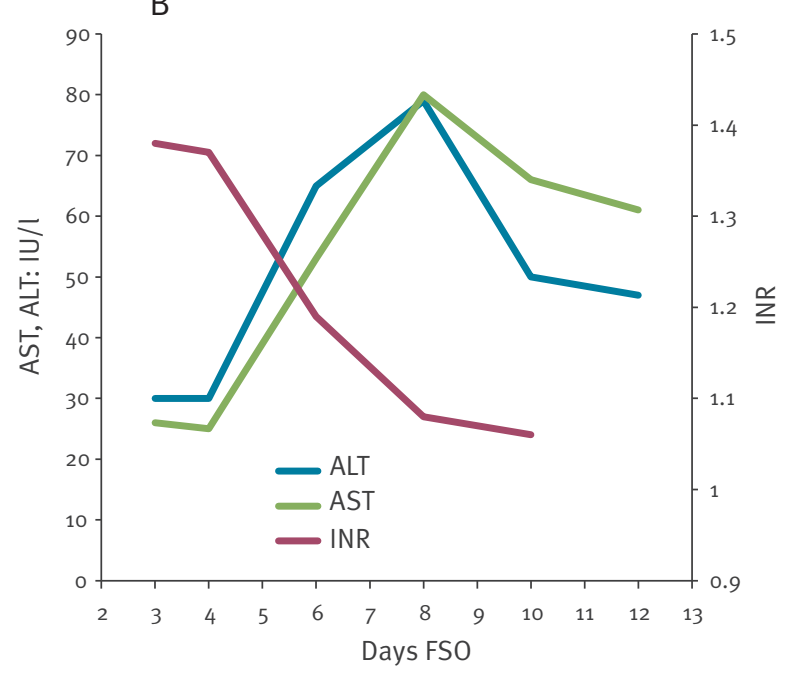

FSO: from symptom onset.

A: white blood cell (WBC) and platelet (PLT) absolute counts.

B: liver enzymes alanine aminotransferase (ALT), aspartate aminotransferase (AST), international normalised ratio (INR).

undetectable in SNF, while it was detected in PeF (Ct: 35.89).

On day 36 FSO, DENV-RNA was no longer detectable in serum, urine, saliva, total VSTM and SNF and PeF (Table).

Specific IgM became detectable on day 10 FSO, and IgG and IgM titres rose on day 18 FSO (1/16o and $1 / 80$, respectively) and on day $36(1 / 320$ and $1 / 160$, respectively). Viral isolation from vaginal samples using VeroE6 cell culture was not successful.

\section{Background}

DF is an arthropod-borne viral infection, transmitted to humans through mosquito bites and caused by DENV, a single stranded, positive-sense RNA virus, belonging to the genus Flavivirus, like Zika virus (ZIKV) and West Nile virus (WNV). Four serotypes (from 1 to 4 ) have been identified so far and each DENV serotype accounts for multiple phylogenetically-related genotypes [2]. DENV is widely diffused, causing more than 58 million symptomatic infections in 2013 [3]. Infection during pregnancy can cause severe maternal and neonatal complications $[4,5]$, However, no fetal abnormalities have been reported so far after DENV infection in pregnant women. Vertical transmission has been described in several reports $[6,7]$, whereas sexual transmission of DENV has never been reported.

\section{Discussion}

The recent ZIKV outbreak evidenced the occurrence of vertical transmission of the virus with fetal abnormalities [8] and male-to-woman, woman-to-male and maleto-male sexual transmission [9], and highlighted the presence of infectious virus in almost all body secretions, including those from male and female genital tract [10-13].

Here we report on DENV-RNA detection in vaginal secretion of an acute case of primary DF. Moreover, we report the detection of viral RNA with the pellet fraction of vaginal secretion after centrifugation. This could reflect DENV association to vaginal epithelial cells, although association with other components of the pellet may not be ruled out. Although vaginal shedding of DENV was protracted up to 18 days FSO, we were not able to isolate replication competent virus from the different fractions derived from genital secretion, probably because of low viral loads detected in the vaginal swab, influence of sample $\mathrm{pH}$ and virus particles degradation. However, our findings could give a deeper insight in DENV sexual and vertical transmission.

Little is known about vertical transmission of DENV and a recent meta-analysis by Xiong et al. [14], failed to demonstrate that maternal DENV infection during pregnancy might increase the risk of premature birth, low birth weight, miscarriage and stillbirth. DENV has been identified in newborns after Caesarean section and the virus was isolated from umbilical cord blood, indicating the possibility of intrauterine acquisition of the infection; the presence of the virus in the vaginal mucosa, shown in our patient, is consistent with the possibility that DENV can be vertically transmitted also during vaginal delivery, similarly to genital herpes [15].

Interestingly, an in vitro study by Chan et al. [16] demonstrated the ability of DENV type 2 to replicate in human cell lines derived from the cervix (HeLa) while no viral growth was observed in experimental infection of placenta (JEG-3), endometrium (HOSE6-3), prostate (LNCaP) and testis (833KE) cell lines. Conversely, 
Dengue virus-RNA detection and serology at different time points, case of dengue fever, Italy, April 2017

\begin{tabular}{|c|c|c|c|c|c|c|c|c|c|}
\hline \multirow{3}{*}{$\begin{array}{l}\text { Days } \\
\text { FSO }\end{array}$} & \multicolumn{6}{|c|}{ DENV-RNA RT-PCR } & \multicolumn{3}{|c|}{ DENV serology } \\
\hline & Serum & Urine & Saliva & \multicolumn{3}{|c|}{ Vaginal swab } & $\lg M$ & $\lg G$ & NS1 \\
\hline & & & & Total VSTM & PeF & SNF & & & \\
\hline 3 & NA & NA & NA & NA & NA & NA & $\mathrm{Neg}^{\mathrm{a}}$ & $\mathrm{Neg}^{\mathrm{a}}$ & Pos $^{a}$ \\
\hline 4 & $\begin{array}{c}\text { Pos } \\
\text { (Ct: 22.00) }\end{array}$ & $\begin{array}{c}\text { Pos } \\
\text { (Ct: } 34.61)\end{array}$ & $\begin{array}{c}\text { Pos } \\
\text { (Ct: } 33.55)\end{array}$ & $\begin{array}{c}\text { Pos } \\
\text { (Ct: } 30.71)\end{array}$ & NA & NA & $<1: 20$ & $<1: 20$ & NA \\
\hline 10 & $\begin{array}{c}\text { Pos } \\
\text { (Ct: } 32.96) \\
\end{array}$ & $\begin{array}{c}\text { Pos } \\
\text { (Ct: } 31.50) \\
\end{array}$ & $\begin{array}{c}\text { Pos } \\
\text { (Ct: } 37.29) \\
\end{array}$ & $\begin{array}{c}\text { Pos } \\
\text { (Ct: } 35 \cdot 47) \\
\end{array}$ & $\begin{array}{c}\text { Pos } \\
\text { (Ct: } 35.47)\end{array}$ & $\begin{array}{c}\text { Pos } \\
\text { (Ct: } 33.34)\end{array}$ & $1: 20$ & $<1: 20$ & NA \\
\hline 18 & Neg & $\begin{array}{c}\text { Pos } \\
\text { (Ct: } 32.53) \\
\end{array}$ & Neg & Neg & $\begin{array}{c}\text { Pos } \\
\text { (Ct: } 35.89)\end{array}$ & Neg & $1: 80$ & 1:160 & NA \\
\hline 36 & $\mathrm{Neg}$ & Neg & Neg & $\mathrm{Neg}$ & Neg & $\mathrm{Neg}$ & 1:160 & $1: 320$ & NA \\
\hline
\end{tabular}

a Rapid test.

Ct: cycle threshold; DENV: dengue virus; FSO: from symptom onset; NA: not available; Neg: negative; PeF: pelleted fraction; Pos: positive; SNF: supernatant fraction; VSTM: vaginal swab transport medium.

all the above-mentioned cell lines were susceptible to ZIKV [16].

Further investigations in individuals with acute DF are needed in order to understand the implications of DENV genital shedding on vertical and sexual transmission. Viral isolation and innovative molecular methods to detect DENV in the replicative phase represent essential steps in this process.

\section{Acknowledgements}

This study was funded by Ricerca Corrente of the Italian Ministry of Health.

\section{Conflict of interest}

None declared.

\section{Authors' contributions}

Marco lannetta, Maria Musso, Alessandra D’Abramo, Laura Scorzolini and Pierangelo Chinello were the physicians in charge of the patient; Eleonora Lalle, Fabrizio Carletti and Concetta Castilletti were the virologists in charge of the virological assays for Dengue virus diagnosis; Marco lannetta wrote the manuscript. Maria R. Capobianchi, who is responsible for the Laboratory of Virology, Giuseppe Ippolito, who supervises all the clinical and translational research on emerging and re-emerging pathogens and Emanuele Nicastri, who is Head of the High Intensity of Care and Highly Contagious Infectious Disease Unit, contributed to the discussion and reviewed the manuscript.

\section{References}

1. Moureau G, Temmam S, Gonzalez JP, Charrel RN, Grard G, de Lamballerie X. A real-time RT-PCR method for the universal detection and identification of flaviviruses.Vector Borne Zoonotic Dis. 2007;7(4):467-77. DOI: 10.1089/vbz.2007.0206 PMID: 18020965
2. Simmons CP, Farrar JJ, Nguyen V, Wills B. Dengue.N Engl J Med. 2012;366(15):1423-32. DOI: 10.1056/NEJMra1110265 PMID: 22494122

3. Castro MC, Wilson ME, Bloom DE. Disease and economic burdens of dengue.Lancet Infect Dis. 2017;17(3):e70-8. DOI: 10.1016/S1473-3099(16)30545-X PMID: 28185869

4. Carles G, Peiffer H, Talarmin A. Effects of dengue fever during pregnancy in French Guiana.Clin Infect Dis. 1999;28(3):637-40. DOI: $10.1086 / 515144$ PMID: 10194092

5. Waduge R, Malavige GN, Pradeepan M, Wijeyaratne CN, Fernando S, Seneviratne SL. Dengue infections during pregnancy: a case series from Sri Lanka and review of the literature.J Clin Virol. 2006;37(1):27-33. DOI: 10.1016/j. jcv.2006.06.002 PMID: 16843056

6. Yin X, Zhong X, Pan S. Vertical transmission of dengue infection: the first putative case reported in China.Rev Inst Med Trop Sao Paulo. 2016;58(0):90. DOI: 10.1590/s1678 9946201658090 PMID: 27982356

7. Chye JK, Lim CT, Ng KB, Lim JM, George R, Lam SK. Vertical transmission of dengue.Clin Infect Dis. 1997;25(6):1374-7. DOI: 10.1086/516126 PMID: 9431381

8. Perez S, Tato R, Cabrera JJ, Lopez A, Robles O, Paz E, et al. Confirmed case of Zika virus congenital infection, Spain, March 2016. Euro Surveill. 2016;21(24):30261. DOI: 10.2807/15607917.ES.2016.21.24.30261 PMID: 27336620

9. Moreira J, Peixoto TM, Siqueira AM, Lamas CC. Sexually acquired Zika virus: a systematic review.Clin Microbiol Infect. 2017;23(5):296-305. DOI: 10.1016/j.cmi.2016.12.027 PMID: 28062314

10. Murray KO, Gorchakov R, Carlson AR, Berry R, Lai L, Natrajan $M$, et al. Prolonged Detection of Zika Virus in Vaginal Secretions and Whole Blood. Emerg Infect Dis. 2017;23(1):99101. DOI: 10.3201/eid2301.161394 PMID: 27748649

11. Nicastri E, Castilletti C, Liuzzi G, Iannetta M, Capobianchi MR, Ippolito G. Persistent detection of Zika virus RNA in semen for six months after symptom onset in a traveller returning from Haiti to Italy, February 2016.Euro Surveill. 2016;21(32):30314. DOI: 10.2807/1560-7917.ES.2016.21.32.30314 PMID: 27541989

12. Barzon L, Pacenti M, Franchin E, Lavezzo E, Trevisan M, Sgarabotto D, et al. Infection dynamics in a traveller with persistent shedding of Zika virus RNA in semen for six months after returning from Haiti to Italy, January 2016. Euro Surveill. 2016;21(32):30316. DOI: 10.2807/1560-7917. ES.2016.21.32.30316 PMID: 27542178

13. Nicastri E, Castilletti C, Balestra P, Galgani S, Ippolito G. Zika Virus Infection in the Central Nervous System and Female Genital Tract.Emerg Infect Dis. 2016;22(12):2228-30. DOI: 10.3201/eid2212.161280 PMID: 27617352

14. Xiong Y-Q, Mo Y, Shi T-L, Zhu L, Chen Q. Dengue virus infection during pregnancy increased the risk of adverse fetal outcomes? An updated meta-analysis.J Clin Virol. 2017;94:42-9. DOI: 10.1016/j.jcv.2017.07.008 PMID: 28753531

15. Carroll ID, Toovey S, Van Gompel A. Dengue fever and pregnancy - a review and comment.Travel Med Infect Dis. 2007;5(3):183-8. DOI: 10.1016/j.tmaid.2006.11.002 PMID: 17448946 
16. Chan JF-W, Yip CC-Y, Tsang JO-L, Tee K-M, Cai J-P, Chik KK-H,

et al. Differential cell line susceptibility to the emerging Zika

virus: implications for disease pathogenesis, non-vector-borne

human transmission and animal reservoirs. Emerg Microbes

Infect. 2016;5(8):e93. DOI: 10.1038/emi.2016.99 PMID:

27553173

\section{License and copyright}

This is an open-access article distributed under the terms of the Creative Commons Attribution (CC BY 4.0) Licence. You may share and adapt the material, but must give appropriate credit to the source, provide a link to the licence, and indicate if changes were made.

This article is copyright of the authors, 2017. 